\title{
METODIKA MĚŘENÍ PODTLAKU VE SBĚRNÝCH LÁHVÍCH REDONOVY DRENÁŽE
}

\author{
Andrea Sedláčková1, Arnošt Pellant ${ }^{1,2}$, Jan Mejzlík¹, 2, Pavel Rozsíval ${ }^{3}$ \\ 12: $500-503,2010$ \\ ISSN $1212-4117$ \\ ${ }^{1}$ Univerzita Pardubice, Fakulta zdravotnických studií, katedra ošetřovatelství \\ 2Pardubická krajská nemocnice, a. s., Klinika otorinolaryngologie a chirurgie hlavy a krku \\ ${ }^{3}$ Univerzita Pardubice, Fakulta elektrotechniky a informatiky, katedra elektrotechniky
}

\section{ÚVOD}

Od samých začátků chirurgie bylo známo, že po některých chirurgických výkonech je potřeba zajistit odvádění vznikajícího sekretu z rány, který by jinak způsoboval, v důsledku retence, vznik komplikací.

Již od doby Hippokrata byly k pasivní drenáži používány kostěné nebo kovové drény. První takzvaná gravitační drenáž byla aplikována v 1. století našeho letopočtu do dutiny břišní prostřednictvím bronzové trubičky (Čapov, Wechsler a kol., 2001, s. 11, 15).

Aktivní drenáž (,air-vent“ sánî) objevil Heaton v roce 1889 (Čapov, Wechsler a kol., 2001, s. 12). S vývojem techniky se postupně zvyšovaly i nároky na vlastnosti materiálu a účinnost drenáže. $Z$ pouhého př́ležitostného a nesystematického využívání drénů se tak vyvinula důležitá metoda, která má své nezastupitelné místo pro léčbu ran ve většině medicínských oborů (Čapov, Wechsler a kol., 2001, s. 12).

Podtlakové drenážní systémy jsou široce rozšířeny např́íč chirurgickými obory. Podtlaku a jeho monitorování uvnitř vakuových sběrných nádob však nebyla $\mathrm{v}$ dostupné literatuře prozatím věnována pozornost.

Předpokládanou první etapou výzkumu a cílem této práce je popsat metodiku měření podtlaku v podtlakových drenážních systémech. Metodou lze ověrit, zda Redonovy láhve značky Drenofast plní po celou dobu svého použití u pacientů svoji funkci a tím se výrazně podílejí na snížení rizika pooperačních komplikací (nejčastěji infekce).

\section{Systém Redonovy drenáže}

Drenážní systém lze dělit z několika pohledů. Kromě rozlišení pasivní a aktivní drenáže je nejvíce používáno rozdělení na otevřený, polootevřený a uzavřený systém (Čapov, Wechsler a kol., 2001, s. 23; Wirbel, Mutschler, 2001, s. 290-295). V naší práci jsme se zaměřili na aktivní sací (podtlakový) drenážní systém, který byl do praxe zaveden roku 1945 Redonem. Ten se stal známým až díky společné publikaci francouzských lékařu Redona, Josta a Torquese v roce 1954 (Wirbel, Mutschler, 2001, s. 290295; Knobloch et al., 2009, s. 137-140). Jedná se o uzavřený typ tzv. podtlakové vakuové drenáže. Systém umožňuje nasávání tekutých médií ve tkáních přes perforovaný drén (dnes Redonův drén) prostřednictvím vytvořeného vakua ve sběrné láhvi. Tím se zabraňuje vzniku retence sekretu, snižuje se riziko komplikací hojení rány a podporuje se hojení rány per prima (Čapov, Wechsler a kol., 2001, s. 128-130; Wirbel, Mutschler, 2001, s. 290-295). Studie týkající se funkce drenážního systému prokázaly, že sací síla drenáže je ovlivněna souhrnem všech jednotlivých proudů, které jdou přes otvory ve stěnách samotného drénu. Toto proudění má turbulentní charakter a je ovlivněno součtem všech ploch postranních otvorů drénů k ploše průřezu sběrného kanálu (Bunte, 1995, s. 1-2). Reichardt a Tollmien zjistili, že nejvíce nasávají postranní otvory v zadní části sběrného kanálu než otvory v přední části (Bunte, 1995, s. 1-2).

$\mathrm{Na}$ trhu se první podtlakové láhve objevily v roce 1959 (Čapov, Wechsler a kol., 2001, s. 129). V současné době je tento drenážní systém standardně používán $\mathrm{v}$ celém světě. Láhve jsou vyrobeny z průhledného plastu, aby manipulace s nimi byla co nejlehčí. Každá sběrná nádoba má na sobě indikátor podtlaku (plastová harmonika), který nás změnou své polohy upozorňuje na výkyvy podtlakových hodnot. V současnosti některé firmy vyrábějí sběrný systém, který umožňuje kontrolu podtlaku pomocí indikátoru zabudovaném v průhledném obvodovém plastovém válci. Válec je graduova- 
ný, nejčastěji ukazuje hodnotu maxima a minima. Takto by mělo být zajištěno vizuální hodnocení podtlakového gradientu. Průhlednost, kalibrace, adekvátní velikost (objem 200-600 $\mathrm{ml})$, těsnost, možnost uzávěru, tolerance pacientem a možnost následné rehabilitace jsou dnes již samozřejmostí (Čapov, Wechsler a kol., 2001, s. 129).

Systém vakuové drenáže našel své uplatnění v oborech, jako jsou břišní chirurgie (včetně operačních zákroků v oblasti retroperitonea), hrudní chirurgie (operace prsní žlázy, štítné žlázy, zákroky na hrudní stěně), chirurgie kostí a velkých kloubů (osteosyntézy), plastická chirurgie, urologické a gynekologické výkony (Čapov, Wechsler a kol., 2001, s. 130; Švrňáková et al. 2005; Pellant et al. 2006)

Trvalý zájem o zdokonalení podtlakové drenáže přinesl další postupy a dělení drenážních systémů dle hodnot tlaku, který se využívá k nasávání tekutých médií.

Nízkotlaký drenážní systém pracující na principu podtlaku o hodnotě $-400 \mathrm{mmHg}$ nemá velké využití. $K$ jeho hlavní nevýhodě patří rychlost poklesu podtlaku (Čapov, Wechsler a kol., 2001, s. 131). Díky této skutečnosti se zvyšují nároky na kontrolu jeho funkčnosti. $\mathrm{V}$ domácí literatuře je tento typ zmíněn pouze okrajově. $\mathrm{V}$ zahraničních studiích, $\mathrm{v}$ rámci některých pooperačních stavů (např. po exenteraci axily pro nádorové onemocnění prsu), bylo při srovnávání nízkotlakých a vysokotlakých drenáží zjištěno, že mají stejný účinek při prevenci tvorby seromu a infekce (Baas-Vrancken et al., 2005, s. 271-275).

Vysokotlaký drenážní systém dosahuje hodnoty vakua $-700 \mathrm{mmHg}$ (800-900 mbar). Předpokládá se, že díky takto vysokému podtlaku se prodlužuje účinnost drenážního systému a tím se prímou měrou ovlivňuje množství odvedeného sekretu, délka hojení rány a samotná hospitalizace pacientů. Proto se více využívají vysokotlaké láhve než nízkotlaké. Na druhé straně komplikací způsobenou vysokým tlakem může být místní poškození tkání (hlavně parenchymatózních orgánů). Nedoporučuje se jejich uložení především do bezprostřední blízkosti nervově-cévních svazků, anastomóz (podpora vzniku píštěle) a nesmí se aplikovat do dřeňové dutiny kostí (Čapov, Wechsler a kol., 2001, s. 130131). Vlivem nasávání a zvyšování média ve sběrné láhvi se tlakový gradient mění. Na po- kles tlakového gradientu by měl upozornit již zmiňovaný indikátor podtlaku. Je ovšem otázkou, za jakých podmínek tento indikátor svoji polohu změní. Otázkou zůstává, zda je změna tlaku paralelně ovlivněna množstvím média (v mililitrech) a kolik mililitrů postačuje k tomu, aby vakuum kleslo na takovou hodnotu, že se drenážní systém stane spíše neúčinným.

\section{Metodika}

Funkčnost drenážního systému je hodnocena na podkladě permanentně zavedeného čidla exkluzivně vytvořeného pro tento typ měření. Čidlo snímá hodnoty ve sběrné láhvi a ukládá je do paměti. Dílčí cíl tak spočívá v prvotním měření hodnoty podtlaku ve vysokovakuové drenážní láhvi, kde se deklaruje hodnota vakua na $-700 \mathrm{mmHg}$. Pilotní výzkum probíhal za konstantních laboratorních podmínek na deseti na sobě nezávisle vybraných kompletních drenážních systémech Drenofast. Výsledkem bylo zjištění, že velikost jejich podtlaku nedosahovala požadovaných hodnot a mnohdy se naměřená hodnota blížila spíše $\mathrm{k}$ hodnotám nízkovakuových láhví (vakuum $-400 \mathrm{mmHg}$ ). Hodnota nastaveného podtlaku ještě před jejich zavedením do operační rány nebyla ani u jednoho náhodně vybraného systému $-700 \mathrm{mmHg}$. Hodnota vakua se pohybovala v rozmezích -525$660 \mathrm{mmHg}$. Z prvotně vytvořených testovacích čidel, jež se zaváděla intermitentně, jsme získali výsledky, které ukazovaly na nepřesnost změny polohy indikátoru podtlaku (při tlaku v láhvi $127 \mathrm{mmHg}$ a množství sekretu v láhvi $60 \mathrm{ml}$ indikátor svoji polohu nezměnil). Tento stav mohl být ovlivněn i skutečností, že v době pooperační došlo k nasátí vzduchu do drenážní baňky a vakuum tak muselo být znovu vytvořeno pomocí centrálního odsávání. Nabízí se otázka, zda by $\mathrm{v}$ těchto prípadech neměla být vyměněna láhev za novou.

Před napojením na sběrný systém s podtlakem je provedena montáž trojcestného kohoutu, který umožní napojení čidel k systému. Čidlo je na sběrnou nádobu připevněno pomocí suchého zipu, který umožñuje jeho následné odlepení po odstranění Redonovy drenáže. Čidlo má výstupkový konektor spojený s trojcestným kohoutem pomocí prridané spojovací hadice, do které je umístěn, tzn. že ze sběrné láhve nevystupuje jedna spojovací hadice, ale dvě. Jedna je napojena na Redonův drén a druhá k čidlu. Pro 
zlepšení komfortu pacienta jsou obě hadice sběrné láhve spojeny pomocí samolepicího zipu. To zabrání i možnosti, že by se do přidané spojovací hadice nasávalo médium z operační rány při průchodu trojcestným kohoutem. Ve chvíli zavedení čidel je spuštěn systém měření, který zhodnotí podtlaky $\mathrm{v}$ nádobě na začátku měření. To nám již na začátku umožňuje eliminovat možnost použití nádob, které nedosahují alespoň podtlaku príbližujícího se $\mathrm{k}$ vysokovakuové hodnotě. Je zapotřebí také neopomenout fakt, že tlak v takovémto systému lehce poklesne také díky znásobení hadic. Pokles podtlaku je však zanedbatelný. Poté jsou čidla naprogramována tak, aby sama v 10minutových intervalech měrila hodnoty a ukládala si je do paměti. Pro vizuální kontrolu činnosti jsou čidla opatřena LCD displejem a jejich chod je udržován bateriovým provozem s nízkou spotřebou. Pro uchování naměřených hodnot je prridána 4Mbit Flash pamět'. Protože velikost podtlaku je dána i množstvím média ve sběrných láhvích, jsou $\mathrm{v}$ pravidelných intervalech hodnoceny i tyto parametry.

Sběrné láhve značky Drenofast jsou vybrány náhodně vzhledem $\mathrm{k}$ jejich širokému využití. Žádný jiný systém jsme v současné době netestovali. Předpokládáme, že funkce podtlakových sběrných nádob je již na začátku ovlivněna hodnotou vakua, která je nastavena z firemní výroby. Tuto skutečnost zatím není možno zjistit žádnými metodami. I přesto, že láhve mají ukazatel indikátoru podtlaku, se na něj nelze zcela spolehnout. Změna jeho polohy, která nás informuje o snižování vakua, není signifikantní a neodpovídá faktickému poklesu. Přitom právě schopnost odvádět médium $\mathrm{z}$ rány je dána hodnotou vakua, která se během doby zavedení mění na podkladě zvyšujícího se množství odvedeného sekretu.

\section{Instrumentace čidel}

Měricí zařízení bylo vyvinuto katedrou elektrotechniky. Jedná se o systém využívající rezistivní tlaková čidla MPXA6115AC6U s rozsahem 110 $-860 \mathrm{mmHg}$ absolutně a MPX5100DP rozsahem 0.--750 $\mathrm{mmHg}$ relativně s maximální chybou cca $11 \mathrm{mmHg}$ pŕi rozsahu teplot $0-85^{\circ} \mathrm{C}$. Čidlo je schopno pracovat při teplotách do $125^{\circ} \mathrm{C}$, ale již s nižší přesností. Hodnota je s nastavitelnou periodou ukládána do paměti s kapacitou až 48 tisíc měření. Samotné čidlo je vzduchotěsné a nemělo by zpo̊sobovat pokles tlaku v systému. K systému se prripojuje pomocí hadičky, jejíž podtlakování nádobkou může při připojení způsobit jednorázově nepatrný pokles tlaku $<2 \mathrm{mmHg}$. Čidlo je složeno $z$ procesoru a paměti, funkčnost zajišt'ují čtyři tužkové baterie. Logovací zařízení umožňuje samočinné měření tlaku se zadaným intervalem. Čidlo má pouze jeden ovládací prvek (čtyřsměrový joystick). Naměřené hodnoty je možné odečitat okamžitě na displeji nebo stáhnout a zpracovat později pomocí počítače. Připojení k počítači je umožněno pomocí kabelu JACK-USB, který se $\mathrm{v}$ počítači zobrazí jako COM port. V počítači je nutné mít nainstalované ovladače. Výsledný soubor lze otevrrít pomocí programu Excel nebo jiným tabulkovým editorem.

\section{ZÁVĚR}

Podtlaková drenáž se využívá již více než 50 let. Jedná se o kombinaci drenážní trubice a rezervoáru sekretu, který tekuté médium pojímá pomocí vakua. Je využívaná v mnoha oborech a kritéria, související s jejím užitím, se neustále zvyšují. Důraz je kladen na výkonnost drenáže, biostabilitu a biokompatibilitu. Má nezanedbatelné postavení $\mathrm{v}$ hojení ran, prostřednictvím aktivního nasávání média $z$ operační rány a tím ovlivňuje délku, charakter hojení a předchází možným komplikacím. Komplikace, které se následkem nesprávně fungující podtlakové drenáže mohou objevit, prodlužují hospitalizaci nemocného, ekonomické náklady vynaložené na jeho léčbu a zároveň ovlivňují jeho psychický stav. Výkonnost drenáže je ovlivněna velikostî vakua ve sběrném systému. Velikost podtlaku je vizuálně znázorňována za pomoci indikátoru, který je umístěn na každé sběrné nádobě a jeho poloha se mění při změně vakua. $V$ převážné většině se v České republice těší většímu využití systémy tzv. vysokovakuové. Je to dáno, hlavně v prvních pooperačních dnech, stabilitou jejich tlakového gradientu. Nízkovakuové drenážní systémy takovouto stabilitou nedisponují a péče o ně je časově náročná.

Pro podrobnější pochopení působení vakuové drenáže hojení ran u nemocných po blokových disekcích krčních uzlin pro maligní onemocnění bude prováděn systematický výzkum, který bude předmětem dalších sdělení. 


\section{LITERATURA}

BAAS-VRANCKEN, PEETERS, M.-J. T. F. D., KLUIT, A. B., MERKUS, J. W. S., BRESLAU, P. J.: Short versus long-term postoperative drainage of the axilla after axillary lymph node dissection. A prospective randomized study. Brest Cancor Research and Treatment 93: 271275, Springer, 2005.

BUNTE, H.: Vermeidbare Fehler beim Lege von Thoraxdrainagen. Chir Praxis, 1995, 49, s. 1-2.

ČAPOV, I.; WECHSLER, J. a kol.: Drény a jejich využití $v$ chirurgických oborech. 1. vyd. Praha: Grada Publishing, $2001,180 \mathrm{~s}$.

KNOBLOCH, K.; BUSCHE, M.; VOGT, P. M.: Wunddrainage in der plastischen Chirurgie. J Ästhet Chi. 2: 137 -140. Springer Medizin Verlag, 2009.
PELLANT, A., ŠKVRŇÁKOVÁ, J., MEJZLÍK, J.: Drenáž a pooperační komprese rány jako důležité faktory prevence vzniku kompartment syndromu v oblasti krku. In: Florence, 3, 2006, s. 33-35.

ŠKVRŇÁKOVÁ, J., PELLANT, A., MEJZLÍK, J.: Ošetřovatelská péče o dusícího se nemocného. In: Orsetřovatelství - teorie a praxe moderního ošetřovatelství. 1-2, s. 31-33, 2005, 1212-723X.

WIRBEL, R.; MUTSCHLER, W.: Postoperative Wound Drainage in Surgery of the Locomotor Systém. Ortpedics and Traumatology 9(4): 290-295, 2001.

Andrea Sedláčková et al. and.sed@seznam.cz 